\title{
CORRESPONDENCE
}

\section{Wastage of Skill in the US}

SIR,-The doctrine has been announced by the US government, and publicly supported by some politicians, scientific administrators and even scientists, that the present scarcity of jobs for technically trained men and women is the result of training too many people. I argue that this shortage is artificial, unnecessary, and caused by deliberate governmental policy to save money.

We have been through this before in the great depression of the 1930s. The cause is known, also the cure. Essential national needs are neglected on all sides, for example, in staffing the ever-expanding institutions of higher education, improving the nation's transportation system in all its forms, salvaging what is left of the inner cities, trying to prevent the impending crisis in energy supplies, bringing health care to every citizen whether rich or poor or in between, conserving our natural resources, and providing an adequate standard of living for all in the richest nation on Earth.

The answer is to carry on useful programmes, financed by both public and private sources, including both basic and applied research in universities, governmental laboratories and industrial organizations. To do these things we need all the trained people we can get, and at all levels. Ours is a technological culture and the way to keep it going is by expanded scientific effort, not by killing the goose that lays the golden eggs.

There is no fat cat more content to put up with things as they are than an academic with tenure. I am deeply disturbed that many of my colleagues seem to accept without question the doctrine of over-production of trained people, when the true state of affairs is deliberate under-utilization, reversible by US governmental action. Where would the money come from? The answer is obvious. Stop the war that has killed or wounded a quarter of a million US men, squandered our resources, ruined Vietnam and degraded the US before the world. All this has not cost either China or Russia a single man, nor has it hindered their scientific and technical growth. We in the US, on the other hand, are seeing our strength waste away under misguided governmental policy.

$$
\text { Yours faithfully, }
$$

ROBERT E. JOHNSON

Department of Physiology and Biophysics, University of Illinois,

Urbana,

Illinois 61801

\section{Biochemistry: IJB and EJB}

$\mathrm{SiR},-\mathrm{A}$ recent issue of Nature $(\mathbf{2 2 6}, 51$; 1970) contains a review by Dr J. H. Morris of the newly launched International Journal of Biochemistry (IJB). The review concludes with the statement that "So long as proliferation is the watchword of communication, the only choice is between more issues of the same journals or the addition of new ones. To judge from the progress of recent starters such as the European Journal of Biochemistry $(E J B)$, the subject is big enough for all comers and their respective fates will ultimately depend on the standard of excellence they attain".

I was closely involved with the creation of the $E J B$, being the chairman of the committee that recommended its formation, and secretary-general of the Federation of European Biochemical Societies at the time that this recommendation was accepted. I do not think that there should be any comparison of the $E J B$ with $I J B$.

The $E J B$ is not a "new" journal, in the sense that its creation did not add to the number of existing journals. On the proposal of the Gesellschaft für Biologische Chemie, Springer-Verlag agreed with FEBS to abandon publication of the Biochemische Zeitschrift, with its long and distinguished history, in return for becoming publishers of the $E J B$.

There are, in addition, a number of equally important criteria that serve to distinguish the $E J B$ from the $I J B$. The $E J B$ was only established after the widest consultation within the member societies of FEBS, representing several thousand European biochemists. Its scientific policy is entirely in the control of the federated societies and the continuity of that control is assured through the FEBS Publications Committee, and the journal's editorial and advisory boards -numbering some 70 biochemists from Europe and the United States. The situation of the $I J B$ is very different. It is a private venture with an editorial board of two, from the same university department. It received at least some of its start in life from manuscripts originally submitted to Comparative Biochemistry and Physiology and resubmitted to the $I J B$. (The two journals share a common editor.) It is relevant here to note that in his review of the $I J B$ Dr Morris pointed out that "Each biochemical journal seems to acquire for itself a characteristic slantthe accent in this first issue is very much on comparative enzymology and metabolism".

Yours faithfully, W. J. WHELAN

University of Miami,

Miami,

Florida 33152

\section{Announcements}

\section{University News}

Mark Ptashne has been appointed professor of biochemistry and molecular biology at Harvard University.

Mrs Kathleen Bell has been appointed to the second chair of social studies in the University of Newcastle upon Tyne.

Dr L. J. Challis has been appointed to the third chair of physics and Mr E. F. Williams has been appointed special professor of food hygiene in the Department of Applied Biochemistry and Nutrition, in the University of Nottingham.

\section{Appointments}

Professor P. G. Stein, Queen's College, Cambridge, has been appointed to the University Grants Committee.

Professor A. R. J. P. Ubbelohde, Imperial College, London, has been reappointed a member of the Agricultural Research Council.

Mr C. L. Old, group education officer to Vickers Limited, has been appointed assistant secretary to the Council of Engineering Institutions, in succession to Rear-Admiral I. G. Aylen.

\section{Miscellaneous}

A PRIZE of 5,000 Swiss francs will be awarded by the International Health Foundation for the best study submitted to the foundation on the subject "Gonadal Function in Man between 45 and 55 Years of Age". Papers may deal with any aspect of this subject-clinical, social, or biochemical--and should contain new and original ideas. They should be written in English and should not exceed 2,500 words in length. Quality rather than quantity will influence the final selection. Papers, together with a short curriculum vitae of the author, should be sent to the International Health Foundation, 14 rue de Hollande, 1204 Geneva, Switzerland, to arrive by June 1, 1971. The results will be announced in August 1971. An additional prize of 2,000 Swiss francs may be awarded for the best paper submitted by an author under 35 if the quality of the entries permits. 


\section{British Diary}

Monday, March 22

Air Pollution (6 p.m.) Dr A. J. Robinson, Royal Society of Arts, at John Adam Street, London WC2. (Second of four Cantor Lectures on "Pollution".)

Artificial and Natural Pollution Tests on Outdoor $400 \mathrm{kV}$ Substation Insulators (5.30 p.m.) Mr C. H. A. Ely, Mr R. G, Kingston and $\mathrm{Mr} \mathrm{P}$. J. Lambeth. Institution of Electrical Engineers, at Savoy Place, London WC2.

Circuit Theory (vacation school, twelve days) Institution of Electrical Engineers, at the University College of North Wales, Bangor, North Wales.

Ferrite Microstrips (10.30 a.m. colloquium) Institution of Electrical Engineers, at Savoy Place, London WC2.

Tuesday, March 23

Direct View Storage Tube Displays (6.30 p.m.) Mr A. B. E. Ellis, Institution of Electronic and Radio Engineers, at Colchester.

Negative Ions (four-day conference) Institute of Physics and the Physical Society, at the University of Liverpool.

Nineteenth Century Founders of the Zoological Collections (6.30 p.m.) $\mathrm{Mr}$ A. E. Gunther, British Museum (Natural History) and the Victorian Society, in the Lecture Hall, British Museum (Natural History), Cromwell Road, London SW7.

Radiological Protection and Society (10 a.m.) Society for Radiological Protection, at London.

The Nature of Automation as Part of the Evolutionary Process (5.30 p.m. discussion) Institution of Electrical Engineers, at Savoy Place, London WC2.

The Pattern of Energy Consumption in the $1970 \mathrm{~s}$ (2.30 p.m. colloquium) Institution of Electrical Engineers, at Savoy Place, London WC2.

Wednesday, March 24

Automation Engineering (6.30 p.m.) Professor P. K. M. M'Pherson, Institution of Electrical Engineers, London Gradu- ate and Student Section, at Savoy Place, London WC2.

Combustion Hazards in Industry (7.30 p.m.) $\mathrm{Mr}$ Murray, Oil and Colour Chemists' Association, at the Carlton Hotel, North Bridge, Edinburgh.

Engineer to Entrepreneur (6 p.m. discussion) Institution of Electronic and Radio Engineers, at 9 Bedford Square, London WC1.

Factors Influencing the Choice of a Mill for a Specific Purpose (5.30 p.m.) Professor H. E. Rose, University of London, at King's College, Strand, London WC2. (Last of four lectures on "An Introduction to Comminution Technology".)

Structure and Growth of Thin Films (5th Thin Films Conference), Institute of Physics and the Physical Society, at the University, Southampton.

The Biochemistry of the Covalent Crosslinking in Collagen (5.30 p.m.) Dr Gerald Mechanic, University of London, at the Royal Dental Hospital of London School of Dental Surgery, Leicester Square, London WC2.

The Influence of Technology on the Social Structure (6 p.m.) The Right Rev. I. T. Ramsey, Royal Society of Arts, at John Adam Street, London WC2. (Trueman Wood Lecture.)

Whither Nuclear Power? (5.30 p.m.) Mr E. S. Booth, FRS, Institution of Electrical Engineers, at Savoy Place, London WC2.

Thursday, March 25

Integrated Circuits in $\mathrm{Hi}-\mathrm{Fi}$ Systems (7.30 p.m.) Mr B. A. Reed, Institution of Electronic and Radio Engineers, at the J. J. Thomson Laboratory, University of Reading, Whiteknights Park, Reading, Berks.

Problems in the Development and Manufacture of Perfumes Toiletries (7.30 p.m.) Mr K. J. Aynsley, British Society of Perfumers, jointly with the Society of Cosmetic Chemists GB, at the Institution of Electrical Engineers, Savoy Place, London WC2.
Techniques for Separating Biological Signals from Biological Noise $(2.30$ p.m discussion) Institution of Electrical Engineers, at University College London, Gower Street, London WC1.

Friday, March 26

Aerosols (7.15 p.m.) Mr D. T. Trist, Oil and Colour Chemists' Association, at the Royal Hotel, Bristol.

Glow Discharge-- Electron Beams (5.30 p.m. discussion) Institution of Electrical Engineers, at Savoy Place, London WC2.

Starch: Granule Structure and Technology (symposium) Society of Chemical Industry, Food Group, at the School of Pharmacy, Brunswick Square, London WC1.

Trends in the Design and Application of High Voltage HRC Fuses (5.30 p.m.) Mr J. Feenan, Institution of Electrical Engineers, at Savoy Place, London WC2.

\section{Monday, March 29}

Land Pollution (6 p.m.) Sir Frank Fraser Darling, Royal Society of Arts, at John Adam Street, Adelphi, London WC2. (Third of four Cantor Lectures on "Problems of Pollution".)

\section{Reports and Publications}

not included in the monthly Books Supplement

\section{Other Countries}

Muscum of Comparative Zoology, Harvard University. Breviora. No. 354: Taxonomic and Fcological Notes on some Middle and South American Lizards Echter Genus Ameiva (Tciidae). By Arthur C. and Spcciation Paturns in the Caracaras (Aves: Falconidac). By F. Vuilleumier. Pp. 29. No. 356: On Ncw Species in a New Farthworm Genus from Puerto Rico. By G. E. Gates. Pp. 11, No. 357: P Review of the Fossil Gelumedusidac (Testudines, Pleurodira) of Asia. By Roger C. Wood. Pp. 24. No. 358: South American Anoles: Anolis apollinaris Boulenger 1919, a Relative of $A$. biporcatus Wiegmann (Sauria, guanidac), By Ernest E. Williams. Pp, 11. No. 359: The Swimbladder as a Juvenik Organ in Stromateoid Fishes. By Michacl H. Horn. Pp. 9, No. 360: Mammals from the Farly Cenozoic of Chubut, Argentina. By George Gaylord Simpson. Pp. 13. No. 361: Additions to Knowledge of the Argyrolagidac (Mammalia, Marsupialia) from the Late Cennzoic of Argentina. By George Gaylord Simnson. Pp. 10. No. 362: Addition to Knowledge of Groeberia (Mammalia, Marsunialia) from the MidCenozoic of Argentina. By George Gaylord Simpson. Pp. 17. (Cambridge, Mass.: Muscum of Comparative Zoology, Harvard University, 1970.)

\section{HOW TO BUY NATURE}

Volumes start in January, March, May, July, September and November, but subscriptions may begin at any time.

The direct postal price per subscription is:

12 MONTHS * (52 issues per title)

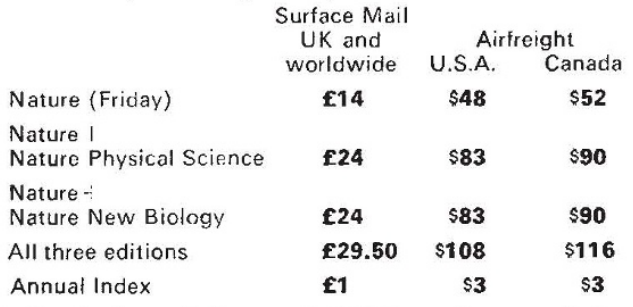

* Rates for shorter periods pro rata (minimum three months)

(Charge for delivery by air mail on application)
Editorial and Publishing Offices of NATURE

MACMILLAN JOURNALS LIMITED 4 LITTLE ESSEX STREET, LONDON WC2R 3LF

Telephone Number: 01-836 6633. Telegrams: Phusis London WC2R 3LF 711 NATIONAL PRESS BUILDING,

WASHINGTON DC 20004

Telephone Number : 202-737 2355

Subscription Department

MACMILLAN JOURNALS LIMITED

BRUNEL ROAD, BASINGSTOKE, HANTS

Telephone Number: Basingstoke 5431

Advertisements only should be addressed to

T. G. SCOTT \& SON, LIMITED

1 CLEMENT'S INN, LONDON WC2A 2ED

Telephone 01-242 6264/01-405 4743

Telegrams: Textualist London WC2A 2ED

Registered as a newspaper at the Post Office

Copyright (c) Macmillan Journals Limited, March 19, 1971 